\title{
The structuring role of macrophytes on plankton community composition and bacterial metabolism in a large subtropical shallow lake
}

\author{
O papel estruturador das macrófitas sobre a composição do plâncton e do metabolismo \\ bacteriano em uma extensa e rasa lagoa subtropical
}

\section{Ng Haig They ${ }^{1 *}$ (D) and David da Motta Marques²}

${ }^{1}$ Departamento Interdisciplinar, Campus Litoral Norte, Centro de Estudos Costeiros, Limnológicos e Marinhos - CECLIMAR, Universidade Federal do Rio Grande do Sul - UFRGS, Avenida Tramandaí, 976, Centro, CEP 95625-000, Imbé, RS, Brasil

${ }^{2}$ Instituto de Pesquisas Hidráulicas - IPH, Universidade Federal do Rio Grande do Sul - UFRGS, Avenida Bento Gonçalves, 9500, Agronomia, CEP 91501-970, Porto Alegre, RS, Brasil

*e-mail: haig.they@gmail.com

Cite as: They, N.H. and Marques, D.M. The structuring role of macrophytes on plankton community composition and bacterial metabolism in a large subtropical shallow lake. Acta Limnologica Brasiliensia, 2019, vol. 31, e19.

Abstract: Aim: We aimed at investigating changes in major groups of plankton (bacterioplankton, phytoplankton and zooplankton) and bacterioplankton metabolism along a transect covering a littoral, macrophyte dominated zone to a pelagic, phytoplankton dominated zone in the large subtropical shallow lake Mangueira, Rio Grande do Sul State, Brazil. Methods: The $3.2 \mathrm{~km}$ littoral-pelagic transect (7 points) was sampled in October 2007 in the southern section of the lake. Major taxonomic groups of phytoplankton and zooplankton were counted and identified by optic microscopy. The bacterioplankton was identified by FISH (Fluorescent in situ Hybridization), and bacterial abundance, biovolume and biomass were quantified by epifluorescence microscopy. Primary and bacterial productions were measured by incorporation of radioactive bicarbonate and leucine, respectively. Bacterial respiration was measured by experiments of oxygen consumption, and an extensive data set of limnological variables were measured through standard methods. Results: Sharp changes in chemical/physical variables, as well as in bacterial density, biovolume, biomass and bacterial growth efficiency occurred on average at $30 \%$ of macrophyte coverage, with most of them increasing towards pelagic zones. The composition of major groups of zooplankton, phytoplankton, bacterial morphotypes and phylotypes indicated that different planktonic assemblies live apart in these two zones. Conclusions Our results demonstrate that macrophytes are a structuring driver of the plankton community and bacterial metabolism in this large subtropical shallow lake.

Keywords: bacterial growth efficiency; bacterial production; bacterial respiration; Fluorescent in situ Hybridization; zooplankton; phytoplankton.

Resumo: Objetivo: Nós objetivamos investigar mudanças nos principais grupos do plâncton (bacterioplâncton, fitoplâncton e zooplâncton) e no metabolismo do bacterioplâncton ao longo de um transecto cobrindo uma zona litorânea dominada por macrófitas para uma zona pelágica dominada por fitoplâncton na lagoa Mangueira, uma lagoa extensa, rasa e subtropical no estado do Rio Grande do Sul, Brasil. Métodos: Um transecto litoral-pelágico de 3,2 Km (7 pontos) foi amostrado em Outubro de 2007 na seção sul da lagoa. Os principais grupos taxonômicos do fitoplâncton 
e zooplâncton foram contados e identificados por microscopia óptica. O bacterioplâncton foi identificado por FISH (Hibridização in situ Fluorescente) e a abundância, o biovolume e a biomassa bacterianas foram quantificadas através de microscopia de epifluorescência. As produçóes primária e bacteriana foram medidas pela incorporação de bicarbonato e leucina radioativos, respectivamente. A respiração bacteriana foi medida através de experimentos de consumo de oxigênio e um conjunto extensivo de variáveis limnológicas através de métodos padrão. Resultados: Mudanças abruptas nas variáveis físicas e químicas, bem como na densidade bacteriana, biovolume, biomassa e eficiência de crescimento bacteriano ocorreram a aproximadamente 30\% de cobertura de macrófitas, com a maior parte delas aumentando em direção à zona pelágica. A composição dos principais grupos do fitoplâncton, zooplâncton, morfotipos e filotipos bacterianos indicou que diferentes comunidades vivem separadas nestas duas zonas. Conclusóes: Nossos resultados demonstram que as macrófitas são o agente estruturador da comunidade planctônica e do metabolismo bacteriano nesta lagoa extensa e subtropical.

Palavras-chave: eficiência de crescimento bacteriano; produção bacteriana; respiração bacteriana; Hibridização in situ Fluorescente; zooplâncton; fitoplâncton.

\section{Introduction}

Macrophytes are a conspicuous feature of subtropical shallow lakes, thriving in their extensive littoral zones and growing continuously due to mild climate conditions. This creates a zonation of dominance of primary producer, with macrophytes being replaced by phytoplankton in pelagic zones of these lakes (Wetzel, 1992).

This shift occurs mostly due to the inhibition of phytoplankton growth through shading, reduced hydrodynamics, competition for nutrients, release of allelopathic substances and increased grazing, which is a consequence of the refuge from predation found by zooplankton (especially large cladocerans) inside plant beds (Scheffer et al., 1993; Scheffer \& Jeppesen, 1997; Søndergaard \& Moss, 1997; van Donk \& van de Bund, 2002; Norlin et al., 2005; Mulderij et al., 2007; also review in Schultz $\&$ Dibble, 2012). However, while the effects of macrophytes on habitat patchiness is well recognized (Docherty et al., 2006), less is known about the impacts of this zonation on whole lake metabolism (Wetzel, 1992; Lauster et al., 2006) and patterns of plankton diversity (but see Mentes et al., 2018). Most importantly, there is a limited knowledge about how the percentage of macrophyte coverage affects the plankton composition, biomass and metabolism, despite consistent evidence of effects of macrophytes on bacterioplankton (Wu et al., 2007; Mentes et al., 2018), phytoplankton and zooplankton (Scheffer \& Jeppesen, 1997)

Bacteria are the major users of dissolved organic matter and therefore of central importance for carbon cycle in aquatic systems (Cole, 1999). Their diversity and metabolism depend strongly on algal primary productivity (Kamjunke et al., 1997; del Giorgio \& Cole 1998; Cotner \& Biddanda, 2002). Along pelagic-littoral gradients, however, phytoplankton-derived carbon may be replaced by macrophytes as the major source of dissolved organic matter (DOM) (Wetzel, 1992). It is well recognized that DOC in natural systems is a complex mixture of unknown origins, composition and proportions and their relative share (autochthonous - from phytoplankton versus allochthonous - from macrophytes) is determinant for the overall ecosystem metabolism (Torremorell et al., 2015). Hence, changes in aquatic metabolism are expected since shifts in carbon quality impact bacterial metabolism, most notably production (They et al., 2010; Torremorell et al., 2015) and respiration (Berggren et al., 2012). Assessing bacterial production and respiration is key to understand ecosystem metabolism, since bacterial production relies on an important share of net primary production and bacterial respiration is typically a major component of total ecosystem respiration (see review in del Giorgio \& Cole, 1998).

Influence of macrophytes and phytoplankton on bacteria has typically been studied by comparisons among systems dominated by either phytoplankton or macrophytes (e.g. Torremorell et al., 2015), seldom in the same system (but see Jeppesen et al., 1998) and with a strong bias towards temperate systems where there is a seasonal die-off of the plants. Studies in temperate lakes have shown that macrophytes may affect indirectly bacterioplankton by providing refuge for large zooplankton from fish predation leading to strong top-down control of the microbial community (Jürgens \& Jeppesen, 1997; Jeppesen et al., 2002). Allelochemicals released by macrophytes may also inhibit bacteria both directly and indirectly, the latter via inhibition of algae (Scheffer \& Jeppesen, 1997; Körner \& Nicklisch, 2002). 
Differently from temperate ecosystems, in subtropical lakes macrophytes are not an effective refuge for zooplankton because of higher fish predation inside plant beds (Meerhoff et al., 2006; Meerhoff et al., 2007). This points to a potential weaker role of zooplankton grazing on phytoplankton and microbial food web components (bacteria, flagellates and ciliates) in macrophyte dominated zones. At the other side, the negative structural and chemical impacts of macrophytes on plankton are permanent and to the present it is unknown which effects (lower grazing pressure $\times$ permanent negative impacts) are predominant for the structuring and metabolism of plankton communities in subtropical shallow lakes. We hypothesize that even under lower predation pressure, littoral zones may present lower densities of planktonic organisms (bacterio-, phyto- and zooplankton), differences in community structure and bacterial metabolism due to changes in water chemistry and major carbon source. In order to test this hypothesis, we surveyed the community structure of major groups of plankton and bacterioplankton metabolic indicators (secondary production, respiration rates and biomass, among other variables) along a gradient of macrophyte to phytoplankton dominance in a large, subtropical shallow lake in southern Brazil. The littoral zones of lake Mangueira have been associated with lower bacterioplankton biomass (They et al., 2010) and respiration (They et al., 2013a), suggesting a lower activity and efficiency in organic carbon cycling by bacterioplankton when compared to the pelagic zones. However, to the best of our knowledge, a detailed description of the changes in plankton diversity and bacterial metabolism along the gradient of macrophyte to phytoplankton dominance zones has not been available for this lake or other subtropical systems. Our goals were i) to elucidate how shifts in primary producer dominance affect the planktonic community, most notably the bacterioplankton, and ii) to determine the percentage of macrophyte coverage at which these shifts occur.

\section{Materials and Methods}

\subsection{Sampling site and approach}

The sampling site chosen was the lake Mangueira, a large, oligo- to mesotrophic, coastal shallow lake (max. depth $6 \mathrm{~m}, 808 \mathrm{~km}^{2}$ ) in Rio Grande do Sul

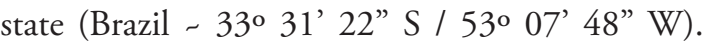
This lake was originated in the last glaciation event during the Pleistocene $(-5,000$ years ago $)$ and despite its proximity to the Atlantic Ocean $(-3 \mathrm{~km})$, it is completely freshwater with no influence of sea salinity.

Sampling was undertaken in late October 2007 along a transect ranging from a densely vegetated littoral area (margin covered by emergent, floating and submerged aquatic macrophytes) to a pelagic, phytoplankton dominated area. The lake is surrounded by a large belt of wetlands, which are particularly massive around the littoral area sampled (Figure 1, Table 1).

The transect length was approximately $3.2 \mathrm{~km}$ comprising seven sampling points arranged not uniformly spaced, but according to decreasing levels of macrophyte coverage (Figure 1). Sub-surface $(-20 \mathrm{~cm}$ depth) water samples were taken in triplicates and handled in a near-shore laboratory for immediate analysis, incubation, and fixation. The depth of each sampling point and a detailed description of the macrophyte's species composition can be found in Table 1 .

\subsection{Limnological variables}

Gran titration alkalinity (Alk) and $\mathrm{pH}$ were assessed through potentiometric methods (Wetzel \& Likens, 2000). Water color (Col), turbidity

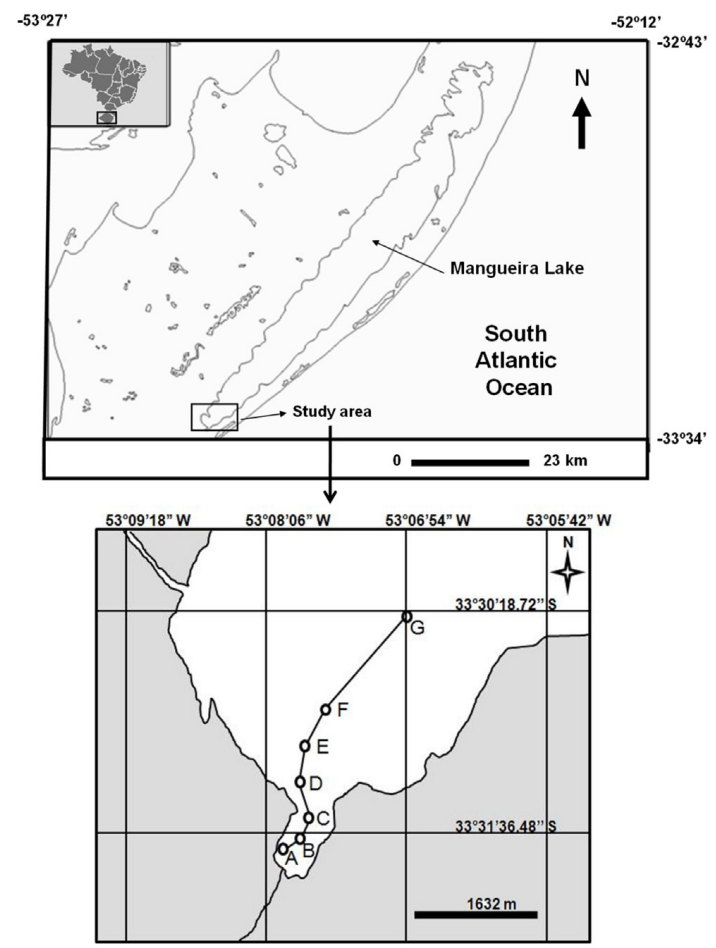

Figure 1. Lake Mangueira (southern end), a coastal large lake in Rio Grande do Sul state, Brazil. Part of transect sampled running from a densely vegetated littoral zone (stations A-C) to a phytoplankton dominated pelagic zone without macrophytes (stations D-G). Total length: $-3.2 \mathrm{~km}$. 
Table 1. Depth of water column and species composition of macrophytes along the sampling points (adapted from They et al., 2015).

\begin{tabular}{ccccc}
\hline Point & Depth $(\mathbf{m})$ & Species composition & Coverage (\%) & Functional group(s) \\
\hline A & 0.50 & $1,2,3,4,5$ & 100 & Submersed \\
B & 0.90 & $3,4,5,6,7,8$ & 75 & Submersed \\
C & 1.10 & 1 & 55 & Submersed \\
D & 1.40 & 1,4 & 25 & Submersed \\
E & 1.90 & 1,4 & 15 & Submersed \\
F & 2.40 & 1 & 5 & Submersed \\
G & 2.90 & - & 0 & Submersed \\
\hline
\end{tabular}

1 - Potamogeton illinoensis (Morong); 2 - Potamogeton pectinatus (L.); 3 - Cabomba caroliniana (Gray); 4 - Egeria densa (Planch); 5 - Myriophyllum spicatum (L.); 6 - Nitella spp. (Agardh); 7 - Ceratophyllum demersum (L.); 8 - Utricularia sp. (L.).

(Turb) and humic substances ratio (HS) were determined through readings at 430,750 and the ratio $250: 365 \mathrm{~nm}$, respectively, using a $1 \mathrm{~cm}$ quartz cuvette in a spectrophotometer (Varian Cary 1E) (Strome \& Miller, 1978). High HS ratios entail proportionally smaller sized dissolved molecules, and expectedly fewer refractory substrates (Strome \& Miller, 1978). Total solids (TS) were assessed gravimetrically after water evaporation in porcelain dishes (APHA, 2006) and dissolved organic carbon (DOC) was determined in a Total Organic Carbon Analyzer (Shimadzu 5000), assumed to be the fraction passing through a membrane filter with $0.45 \mu \mathrm{m}$ pore size according to APHA (2006).

All nutrients were measured spectrophotometrically: ammonium $\left(\mathrm{NH}_{4}^{+}\right)$by the phenol-hypochlorite method, total nitrogen $(\mathrm{TN})$, nitrate $\left(\mathrm{NO}_{3}^{-}\right)$and nitrite $\left(\mathrm{NO}_{2}^{-}\right)$by the sulfanilamide-ethylenediamine method and total phosphorus (TP) and soluble reactive phosphorus $\left(\mathrm{PO}_{4}^{-3}-\mathrm{P}\right)$ by the ascorbic acid method (Mackereth et al., 1989). Silicate $\left(\mathrm{SiO}_{2}\right)$ was quantified with a commercial kit (Si Merck Spectroquant ${ }^{\circledR}$ kit for silicates - silicilic acid).

\subsection{Primary producers}

Phytoplankton samples were collected through concentration of $20 \mathrm{~L}$ of water sample on a $20 \mu \mathrm{m}$ mesh sieve (small algae not included) and fixed in $4 \%$ formaldehyde solution. Samples were stored in darkness at room temperature until analysis (Wetzel \& Likens 2000). The density was determined in Sedwick-Rafter chambers (APHA, 2006) by counting of at least 100 individuals of the most abundant species in an inverted microscope. The results were expressed in number of individuals by water volume (ind $\mathrm{mL}^{-1}$ ). The biomass was also determined in Sedwick-Rafter chambers (APHA, 2006) through counting and biovolume determination of at least 20 individuals (when possible) of each species (Sun \& Liu, 2003; Hillebrand et al., 1999). Fresh biomass $\left(\mathrm{mm}^{3} \mathrm{~L}^{-1}\right)$ was estimated by multiplying biovolume by density of each taxon and application of empirical conversion factors from biovolume to biomass (Wetzel \& Likens, 2000). The community composition of phytoplankton was determined for major groups according to van den Hoek et al. (1998). Chlorophyll $a$ was quantified through cold ethanol extraction (Jespersen \& Christoffersen, 1987).

The primary production (PP) was measured using radioactive sodium bicarbonate $\left(\mathrm{NaH}^{14} \mathrm{CO}_{3}\right)$ (Wetzel \& Likens, 2000). The incubation lasted $4 \mathrm{~h}$ around noon and was carried out in situ at the subsurface (margin area, $\sim 0.5 \mathrm{~m}$ depth) with bottles tied to a floating device. The bottles were then kept in the dark and cool until processing. For reading, samples were filtered $(0.45 \mu \mathrm{m})$, and scintillation liquid Optiphase HiSafe III (Wallac) was added to the filters prior to beta particle emission counting in a Rack Beta Liquid Scintilation Counter (LKB Wallac 1209) for $600 \mathrm{~s}$. Results were expressed in $\mathrm{mg} \mathrm{C} \mathrm{m} \mathrm{m}^{-3} \mathrm{~h}^{-1}$ (Wetzel \& Likens, 2000).

Emergent, floating and submerged aquatic macrophyte coverage was estimated visually by averaging coverage $(0-100 \%$, at $5 \%$ intervals) obtained in $1.0 \mathrm{~m}^{2}$ square quadrats (Braun-Blanquet, 1964).

\subsection{Bacterioplankton}

Samples for cell counting, biovolume, biomass and morphotype determination were first pre-filtered in quantitative paper (MN 640d Macherey-Nagel average mesh size 2.0 to $4.0 \mu \mathrm{m}$ ) in order to exclude other organisms than bacteria and afterwards fixed in 4\% formaldehyde (vol:vol) in polyethylene bottles. Samples were stored in the dark and cool until analysis. 
In the laboratory, $2 \mathrm{~mL}$ of each sample were filtered $(<5.0 \mathrm{kPa})$ in a Vacuum Minifold Filtration Tower (Millipore) with $1 \mathrm{~mL}$ of Mili-Q water $(0.2 \mu \mathrm{m}$ filtered $)$ to improve cell dispersion. Cells were concentrated onto $0.2 \mu \mathrm{m}$ black polycarbonate membranes (GE), stained with $10 \%$ acridine orange and processed within 3 days. A total of 10 images were captured per filter and image processing was undertaken on six of them with the help of an image grab system. We employed a refrigerated camera (MOTIC 5000) coupled to an inverted epifluorescence microscope (Olympus IX70). Image capture (MOTIC Image 3.2) and processing followed Massana et al. (1997) with the help of the software Image Tool (v. 3.00). After processing and binarization, the images were submitted to CMEIAS/Image Tool (v. 1.27) software for cell counting, dimension determination and morphotype classification (Liu et al., 2001).

Bacterial density (BD) was determined from the average number of cells in the 6 images applying the cell density equation described in Kepner Júnior \& Pratt (1994). Bacterial biovolume $\left(\mu \mathrm{m}^{3}\right)$ was assigned to each cell according to morphotype (Massana et al., 1997), utilizing cell dimensions obtained by the CMEIAS/Image Tool (v. 1.27) and the average calculated from all cells in all images. Bacterial biomass ( $\mathrm{BBm})\left(\mathrm{pg} \mathrm{C} \mathrm{cell}^{-1}\right)$ was calculated employing an allometric function of biovolume (Norland, 1993), and the average from all cells in all images was multiplied with the cell density estimation to yield the bacterial carbon concentration of the sample $\left(\mu \mathrm{g} \mathrm{C} \mathrm{mL} \mathrm{mL}^{-1}\right)$. Morphotype distribution (Coccus, Spiral, Curved Rod, U-Shaped Rod, Regular Rod, Unbranched Rod, Ellipsoid, Club, Prosthecate, Rudimentary Branched Rod and Branched Filament) was determined as a percentage from the averages of the morphotypes lists for each image obtained by the CMEIAS/Image Tool (v. 1.27).

Bacterial production (BP) was based in tritium radio-labelled $\mathrm{L}-\left[4,5-{ }^{3} \mathrm{H}\right]$ leucine and micro centrifugation. Calculations assumed intracellular isotopic dilution to be equal to 2 , the molar percentage of leucine in the proteic pool to be equal to 0.073 and the ratio carbon:protein to be equal to 0.86 (Smith \& Azam, 1992; Kirchman, 2001).

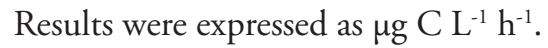

Bacterial respiration (BR) was determined by the classic Winkler method (described in Golterman et al., 1978) from oxygen consumption in dark bottles, and oxygen spectrophotometric readings at $430 \mathrm{~nm}$ modified from Roland et al. (1999). Briefly, bulk samples were pre-filtered through quantitative paper filters (MN 640d Macherey-Nagel - average mesh size 2.0 to $4.0 \mu \mathrm{m}$ ) to isolate bacteria. The incubation was carried out in situ in glass BOD (biological oxygen demand darkened bottles) suspended as described for primary production. Time of incubation was $120 \mathrm{~h}$, because very low consumption rates in pilot tests did not allow oxygen consumption detection before 72 h (They et al., 2013b). The molar conversion factor between carbon and oxygen was assumed to be equal to 1.0 (del Giorgio et al., 1997).

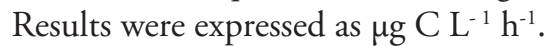

Complementary to $\mathrm{BP}$ and $\mathrm{BR}$, bacterial growth efficiency (BGE) was calculated as $\mathrm{BGE}=(\mathrm{BP}) /(\mathrm{BP}+\mathrm{BR})($ del Giorgio \& Cole, 1998).

Bacterial diversity was evaluated with Fluorescent in situ Hybridization (FISH). Oligonucleotide $16 \mathrm{~S}$ rRNA probes (UNISCIENCE) were employed: Eub338R - domain Bacteria with sub-groups: Alf968 - $\alpha$-proteobacteria; Bet42a - $\beta$-proteobacteria; Gam42a - $\gamma$-proteobacteria; CF319aCytophaga-Flavobacter and also a negative control ([Cy3]5'-CCTAGTGACGCCGTCGAC-3')

(Glöckner et al., 1999). Samples were pre-filtered as described above and $2 \mathrm{~mL}$ of each sample were filtered on $0.2 \mu \mathrm{m}$ polycarbonate membranes (GE) under low pressure $(<5.0 \mathrm{kPa})$. The samples were fixed in paraformaldehyde ( $4 \%$ weight:vol) phosphate-buffer pH 7.2 solution (max. 24 h) and kept frozen at $-20{ }^{\circ} \mathrm{C}$ until hybridization. For this, each filter was divided in parts and each part was hybridized (for 24 hs at $46^{\circ} \mathrm{C}$ ) with $40 \mu \mathrm{L}$ of one of each probe hybridization solution $(\mathrm{NaCl} 0.9 \mathrm{M}$; Tris- $\mathrm{HCl} 20 \mathrm{mM}$ (pH 7.2); formamide 35\% (CF319a) and 30\% (other probes); EDTA $5 \mathrm{mM}$; sodium dodecyl sulphate $0.01 \%$ and $100 \mathrm{ng}$ of oligonucleotide). For total cell counts DAPI stain was used $\left(20 \mu \mathrm{g} \mathrm{mL}^{-1}\right.$ for 5 minutes $)$. Slides were mounted with mineral oil (Nujol) and processed within a week (Pernthaler et al., 2001).

Image processing was done using Image Tool (1.27). A total of 10 fields per probe (filter part) were processed in each filter, resulting in a total of 120 images (60 total DAPI counts and 60 labeled cells counts) per filter. The density of the cells stained by the specific probes was calculated as the average of the mean countings per field after subtracting from the negative control and as described above for cell density estimation (Kepner Júnior \& Pratt, 1994). Results were reported as percentage from group density data: $\alpha$-Proteobacteria, $\beta$-Proteobacteria, $\gamma$-Proteobacteria 
and Cytophaga-Flavobacter assessed by their specific rRNA probes. Other bacteria were computed as EUB338 probe labeled cells (total bacteria density) minus the sum $(\alpha+\beta+\gamma$-Proteobacteria and Cytophaga-Flavobacter). When this sum was higher than EUB338 density, other bacteria were considered equal to zero. Undetermined groups (non bacteria) were computed as total DAPI counts (unspecific stain, total density) minus EUB338 counts or the sum $(\alpha+\beta+\gamma$-Proteobacteria and Cytophaga-Flavobacter), whichever the highest.

\subsection{Zooplankton and ciliates}

Zooplankton samples were collected together with phytoplankton samples $(20 \mathrm{~L}$ samples, as described above). In the laboratory, samples were concentrated in the same sieve $(20 \mu \mathrm{m}$ mesh size) to $30 \mathrm{~mL}$ and counted integrally under an inverted microscope in sedimentation chambers. Total zooplankton density (ZD) was reported as ind $\mathrm{m}^{-3}$. Also a qualitative analysis was carried out for major groups (Cladocera, Copepoda, Nauplii, Rotifera and others) (Wetzel \& Likens, 2000).

For ciliate countings, $2 \mathrm{~L}$ samples were concentrated in a $20 \mu \mathrm{m}$ (mesh size) sieve to $50 \mathrm{~mL}$, fixed with lugol (9:1 vol:vol) and stored in the dark and cool until analysis. Samples were integrally counted in sedimentation chambers using an inverted microscope, and total ciliate density (CD) was reported as ind $\mathrm{m}^{-3}$ (Wetzel \& Likens, 2000).

\subsection{Stoichiometric ratios}

Derived molar ratios between variables were also considered, as there is a general consensus about their change along trophic gradients (measured as chlorophyll $a$ concentration). DOC: $\mathrm{PO}_{4}^{-3}$ and DOC: $\mathrm{NO}_{3}{ }^{-}$are considered as measures of the proportion of organic to inorganic nutrients in the system, which is assumed to decrease along trophic gradients (Cotner \& Biddanda, 2002; del Giorgio et al., 1997). TN:TP refers to the classical Redfield ratio.

\subsection{Statistical analyses}

The direct effect of macrophytes on limnological and biological variables was assessed by linear regressions of each variable against macrophyte coverage $(\mathrm{MC} \%)$ as a predictor. Additionally, a Breakpoint Analysis (Piecewise Regression) was carried out for each variable. This analysis identifies the breakpoint in the predictor variable that produces the minimal residual standard error in the response variable and fits two linear models derived from the break (Crawley, 2007). The objective of this analysis was to identify the $\mathrm{MC} \%$ where the abrupt shift occurred for each variable and detect whether the response of the variables shifts away from the break on both sides.

Redundancy Analyses (RDA) were run with limnological variables as explanatory matrix and five sets of biological variables as response matrices (one at a time). A selection of the explanatory variables was done through variance inflation factors (VIFs). All variables were $\mathrm{z}$-score standardized (except for zooplankton, phytoplankton and bacterial phylotypes and morphotypes, expressed as proportion). The RDA axes were submitted to permutation tests to verify their statistical significance. This analysis followed Borcard et al. (2011).

All analyses and graphic presentations were done in R 2.13.1 (R Development Core Team, 2011). For RDA, the vegan (Oksanen et al., 2011) and calibrate (Graffelman, 2010) packages were used. Graphic presentations employed ggplot2 (Wickham, 2009) and sfsmisc packages (Maechler et al., 2011).

\section{Results}

\subsection{Depth and macrophyte composition}

The depth of the sampling points varied from $0.5 \mathrm{~m}$ in point $\mathrm{A}$ to almost $3.0 \mathrm{~m}$ in point $\mathrm{G}$ (Figure 2). The MC\% decreased from 100\% in littoral zone to $0 \%$ in the pelagic zone and was composed exclusively of submerged rooted macrophytes (hereafter referred as submerged) (Table 1). Other macrophytes did not occur in the sampling points, but surrounding the first of them (points A-D). The emergent macrophytes Schoenoplectus californicus (C. A. Meyer) and Zizaniopsis bonariensis (Balansa \& Poitr.) occurred at a $100 \%$ coverage in large belts and the floating macrophytes Salvinia sp. (Séguier), Pistia stratiotes (L.), Eichornia azurea (Swartz) and Lemna sp. (L.) occurred from $10-100 \%$ coverage very close (minimum of $200 \mathrm{~m}$ of distance) to any of these sampling points (Table 1).

\subsection{General trends in limnological and biological variables}

A marked shift occurred in physical, chemical and biological variables along the transect of change in primary producer dominance (macrophyte to phytoplankton). Some of the limnological variables showed an increasing trend $\left(\mathrm{NO}_{2}^{-}, \mathrm{TP}, \mathrm{PO}_{4}^{-3}, \mathrm{DOC}: \mathrm{NO}_{3}^{-}\right.$, alkalinity, $\mathrm{pH}$, turbidity, HS ratio and total solids) towards the pelagic zone, whereas others decreased (color, N:P and 

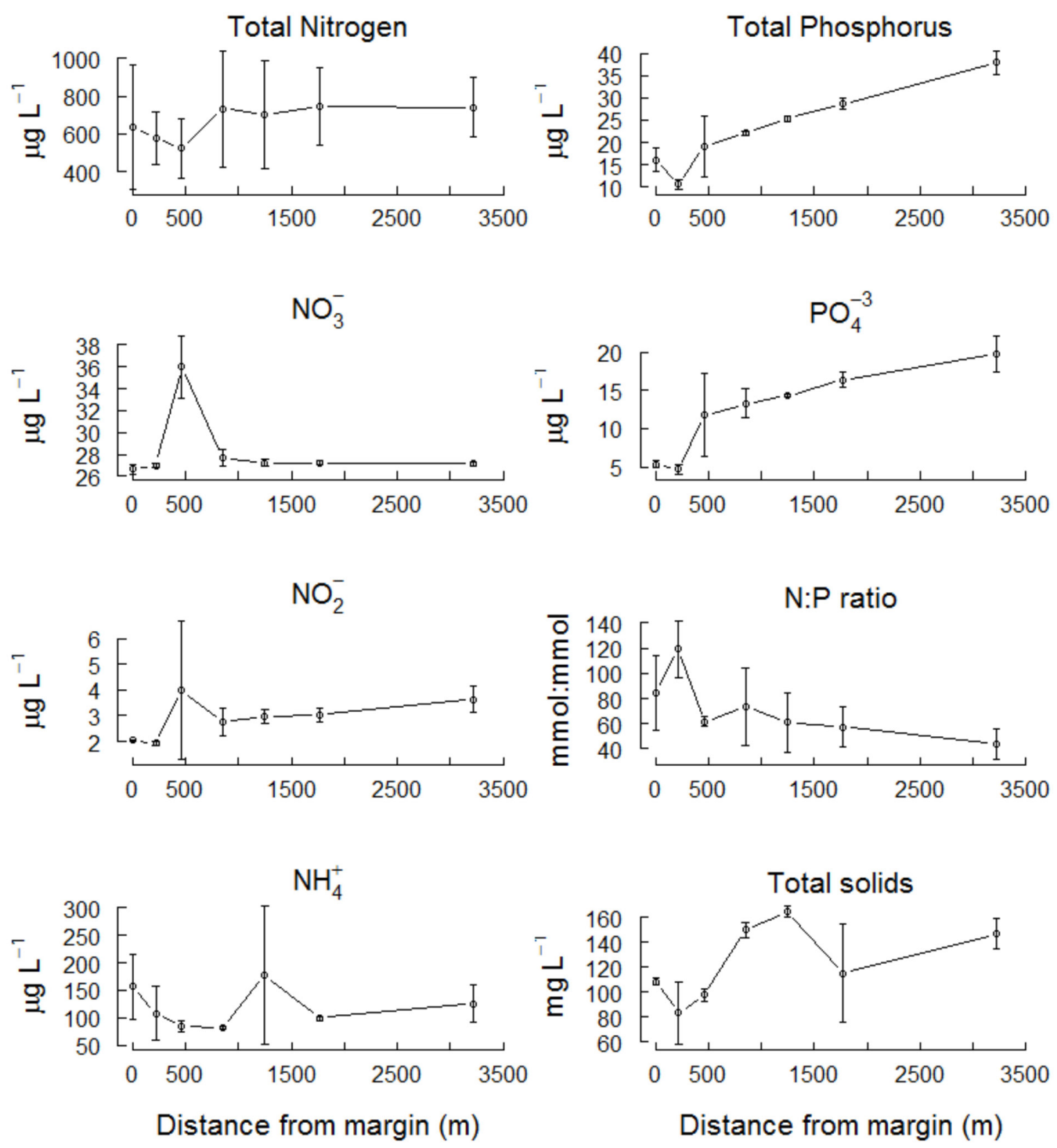

Figure 2. Gradient of inorganic nutrients and total solids along a transect running from a littoral macrophyte dominated zone to a phytoplankton dominated pelagic zone in Lake Mangueira. Bars represent standard deviations $(\mathrm{n}=3)$.

DOC: $\left.\mathrm{PO}_{4}^{-3}\right)$. Some variables showed no apparent change (TN, $\mathrm{NH}_{4}^{+} \mathrm{NO}_{3}^{-}$, DOC) (Figures 2 and 3).

The biomass of most of the variables increased in the pelagic zone: chlorophyll $a$, phytoplankton biomass, bacterial biomass, and primary production. Phytoplankton, zooplankton, and bacterial densities and BGE increased, while ciliate density decreased along the transect. BP increased (ranging on average from $0.15-0.23 \mu \mathrm{g} \mathrm{C} \mathrm{L}^{-1} \mathrm{~h}^{-1}$ in points A-D to 0.22-0.27 $\mu \mathrm{g} \mathrm{C} \mathrm{L}^{-1} \mathrm{~h}^{-1}$ in points E-F), while BR was highest at the first sampling station, dropped around $750 \mathrm{~m}$ from the margin and increased afterwards (Figure 4).

There were changes in the relative proportion of zooplankton, phytoplankton and bacterioplankton groups along the transect. The zooplankton was dominated by nauplii and rotifers in the littoral zone, and by cladocerans further out (Figure 5a). The phytoplankton composition was largely dominated by cyanobacteria and diatoms, with a slight increase in the share of cyanobacteria along the outer half of the transect (Figure 5b). The bacterioplankton was mainly composed of undetermined groups (non targeted by the FISH probes employed) (range: $54.6 \%-98.2 \%$ ), with the exception of around $1.0 \mathrm{~km}$ m of the transect, where a bacterial peak was observed, mainly $\alpha$ - and $\beta$-proteobacteria (range of Bacteria: 1.8\% - 45.4\%) (Figure 5c). Bacterial morphotypes were dominated by coccus and curved rods. The proportion of cocci increased from $-65 \%$ to $-80 \%$ from $1,000 \mathrm{~m}$ of the transect on (Figure $5 \mathrm{~d}$ ). 

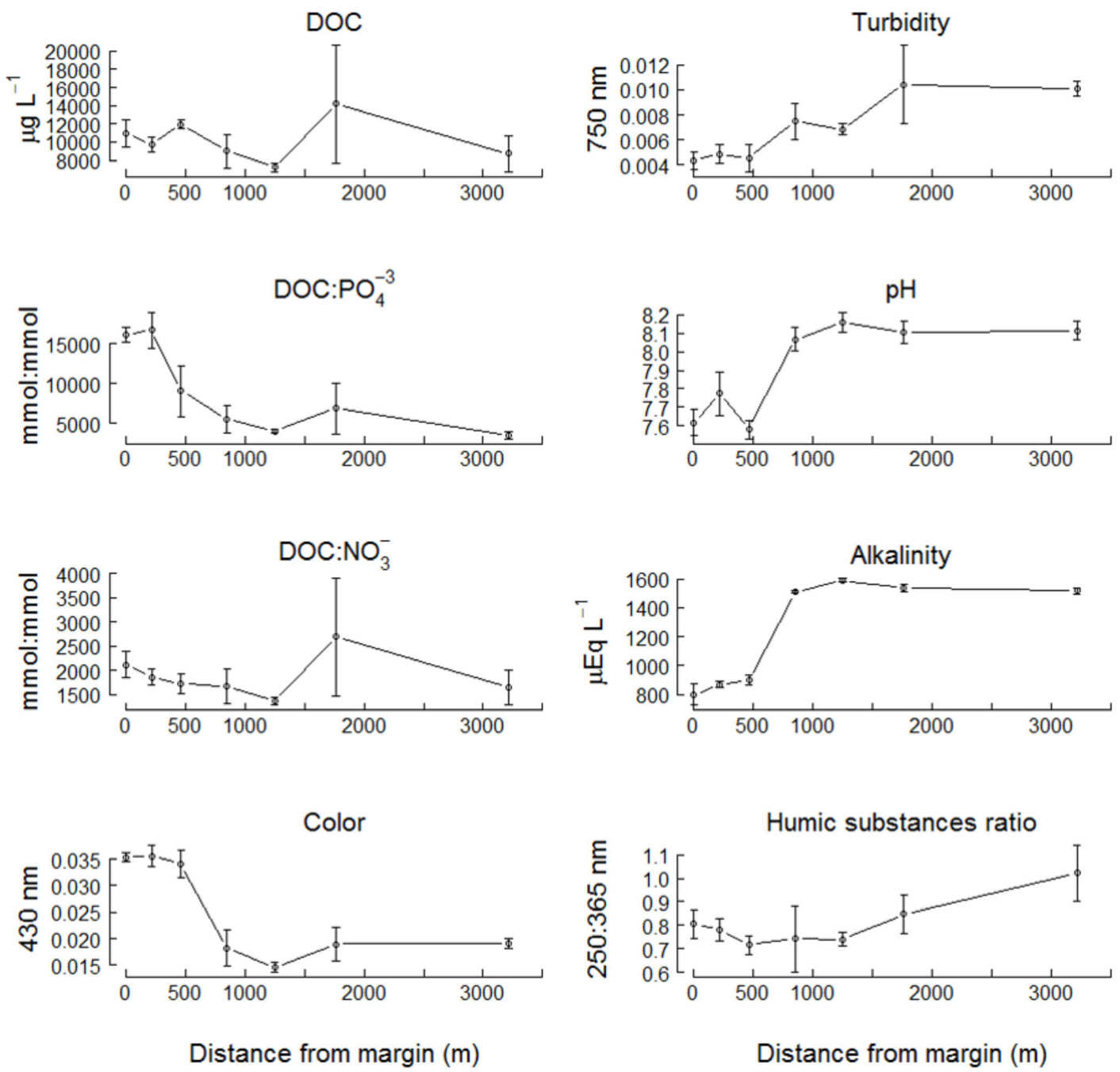

Figure 3. Gradient of the main limnological variables along a transect running from a littoral macrophyte dominated zone to a phytoplankton dominated pelagic zone in Lake Mangueira. Bars represent standard deviations $(\mathrm{n}=3)$.
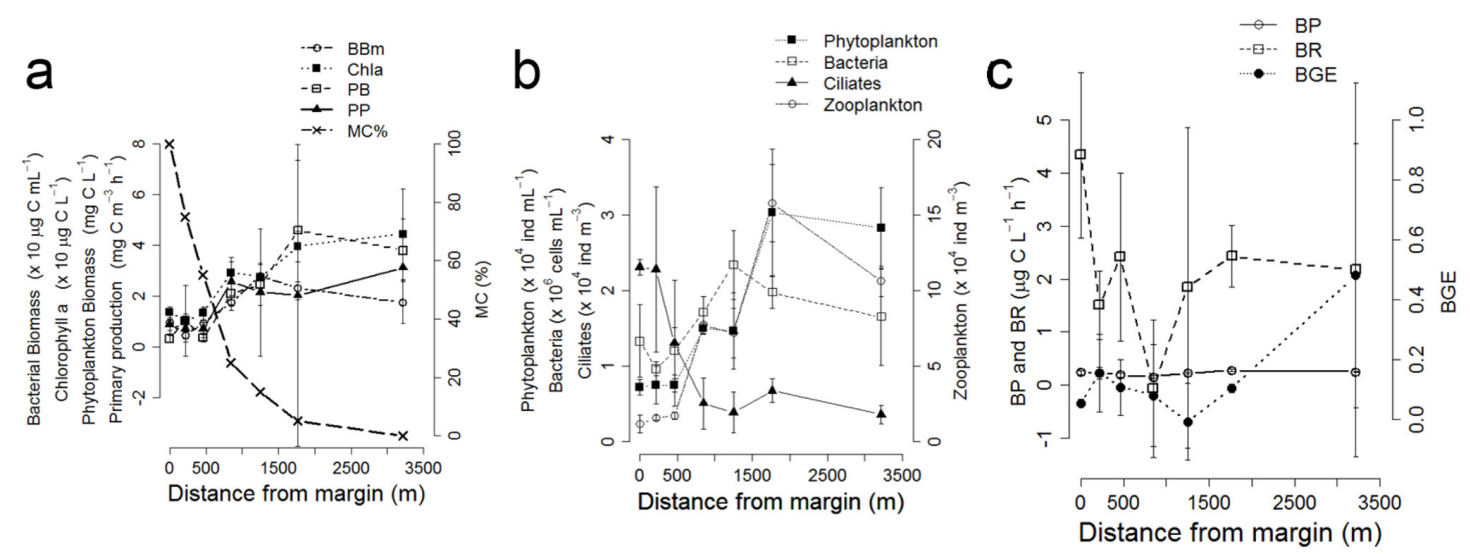

Figure 4. Upper panel (a): bacterial biomass (BBm), chlorophyll a (Chla), phytoplankton biomass (PB), primary production $(\mathrm{PP})$ and macrophyte coverage $(\mathrm{MC} \%)$; middle panel (b): phytoplankton, bacterial, ciliates and zooplankton density; lower panel (c): bacterial production (BP), bacterial respiration (BR) and bacterial growth efficiency (BGE) along a transect running from a macrophyte dominated littoral to a phytoplankton dominated pelagic zone in Lake Mangueira. Bars represent standard deviations $(\mathrm{n}=3)$. 

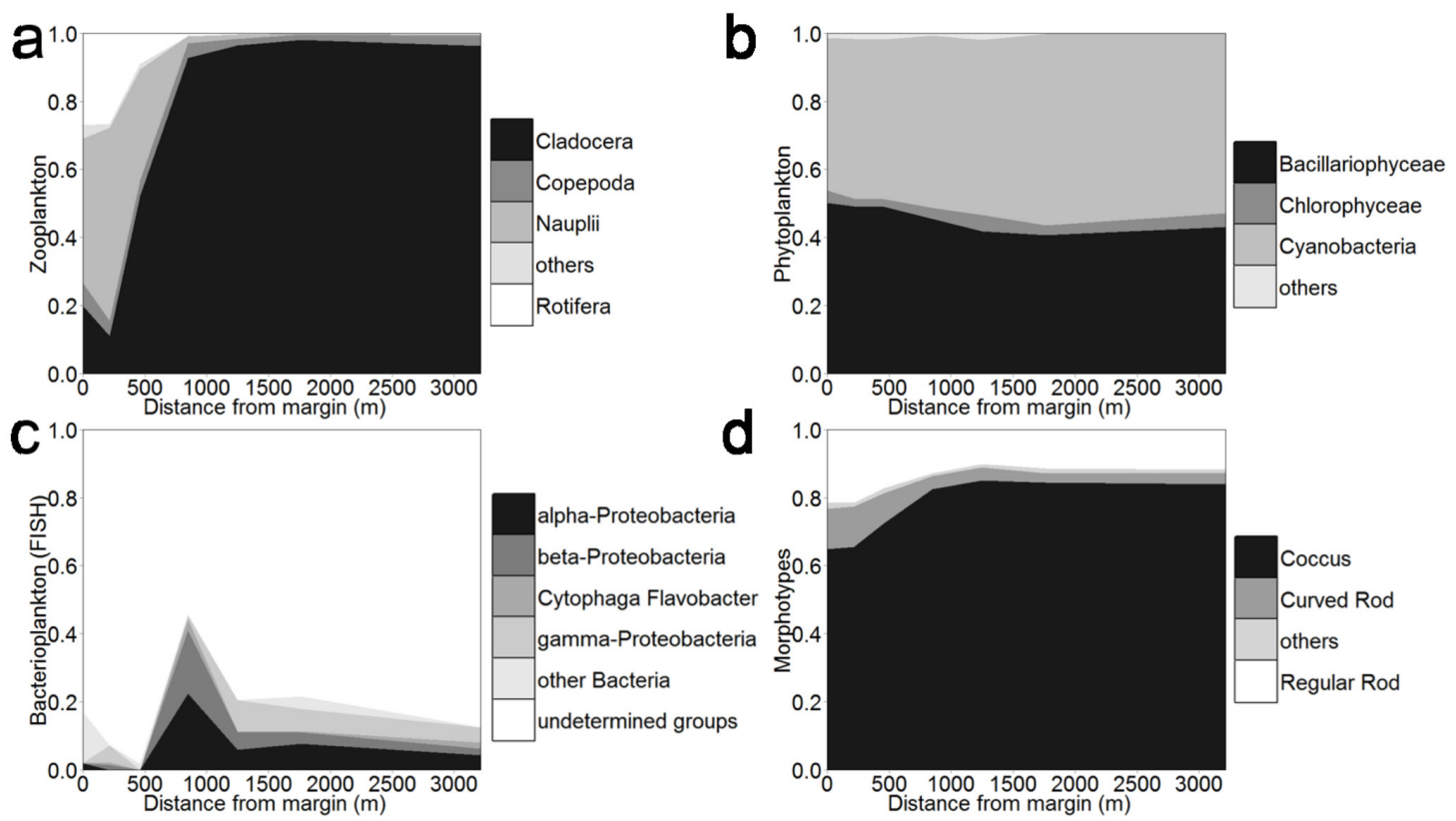

Figure 5. Contribution of major groups of a) zooplankton, b) phytoplankton, c) bacterial phylotypes and d) bacterial morphotypes along a transect running from a macrophyte dominated littoral zone to a phytoplankton dominated pelagic zone in Lake Mangueira. Standard deviations ( $\mathrm{n}=3)$ omitted.

\subsection{Breakpoint analysis}

TP, $\mathrm{PO}_{4}^{-3}, \mathrm{SiO}_{2}, \mathrm{pH}$, alkalinity, turbidity, bacterial biomass, bacterial biovolume, bacterial density, phytoplankton biomass, chlorophyll $a$, primary production, phytoplankton density and zooplankton density were significantly and negatively associated with $\mathrm{MC} \%$, while DOC: $\mathrm{PO}_{4}^{-3}$, ciliate density and color showed a positive association. The breaks that generated significant models in a Breakpoint Analysis varied from $5-75$ of $\mathrm{MC} \%$, with a mean breakpoint of around 30\%. For breakpoint regressions < Break, $\mathrm{TN}, \mathrm{SiO}_{2}$, HS ratio, and chlorophyll a showed a significant negative relationship, while DOC: $\mathrm{NO}_{3}$ had a positive relationship with $\mathrm{MC} \%$. In the breakpoint regressions $\geq$ Break, $\mathrm{TN}, \mathrm{SiO}_{2}$, DOC: $\mathrm{NO}_{3}^{-}$, bacterial production, bacterial respiration and bacterial growth efficiency showed a positive relationship, while TP, $\mathrm{PO}_{4}^{-3}$, turbidity, phytoplankton density, phytoplankton biomass and zooplankton density exhibited a negative relationship with $\mathrm{MC} \%$. Of the breakpoint regression models, the $\mathrm{TN}, \mathrm{SiO}_{2}, \mathrm{DOC}: \mathrm{NO}_{3}^{-}, \mathrm{HS}$ ratio, bacterial production, bacterial respiration, BGE and phytoplankton density breakpoint models were statistically different from the non-breakpoint models (Table 2).

\subsection{Redundancy Analyses (RDAs)}

The selected environmental variables accounted for a significant proportion of the bulk community measurements, bacterial metabolic responses and major planktonic groups ( $>75 \%$ ), except for FISH data (Table 3). The analyses revealed the same patterns already described above and can be seen in more detail in the Figure 6.

\section{Discussion}

Our results corroborated our hypothesis of lower plankton abundance in littoral zones and changes in composition and bacterial metabolism along the littoral-pelagic gradient of Lake Mangueira. These changes can be attributed mainly due to shifts in water chemistry and carbon sources, notably nutrients, ratios between DOC:nutrients and humic substances that were associated with the shift in primary producer dominance along the gradient.

\subsection{Water chemistry}

Macrophytes can exert a strong control on concentrations of carbon and inorganic nutrients in the water. Higher concentration of DOC in the littoral zone is typical from vegetated areas (Wetzel, 1992; Søndergaard et al., 1997; Reitner et al., 1999). Contrastingly, in this study DOC was not 


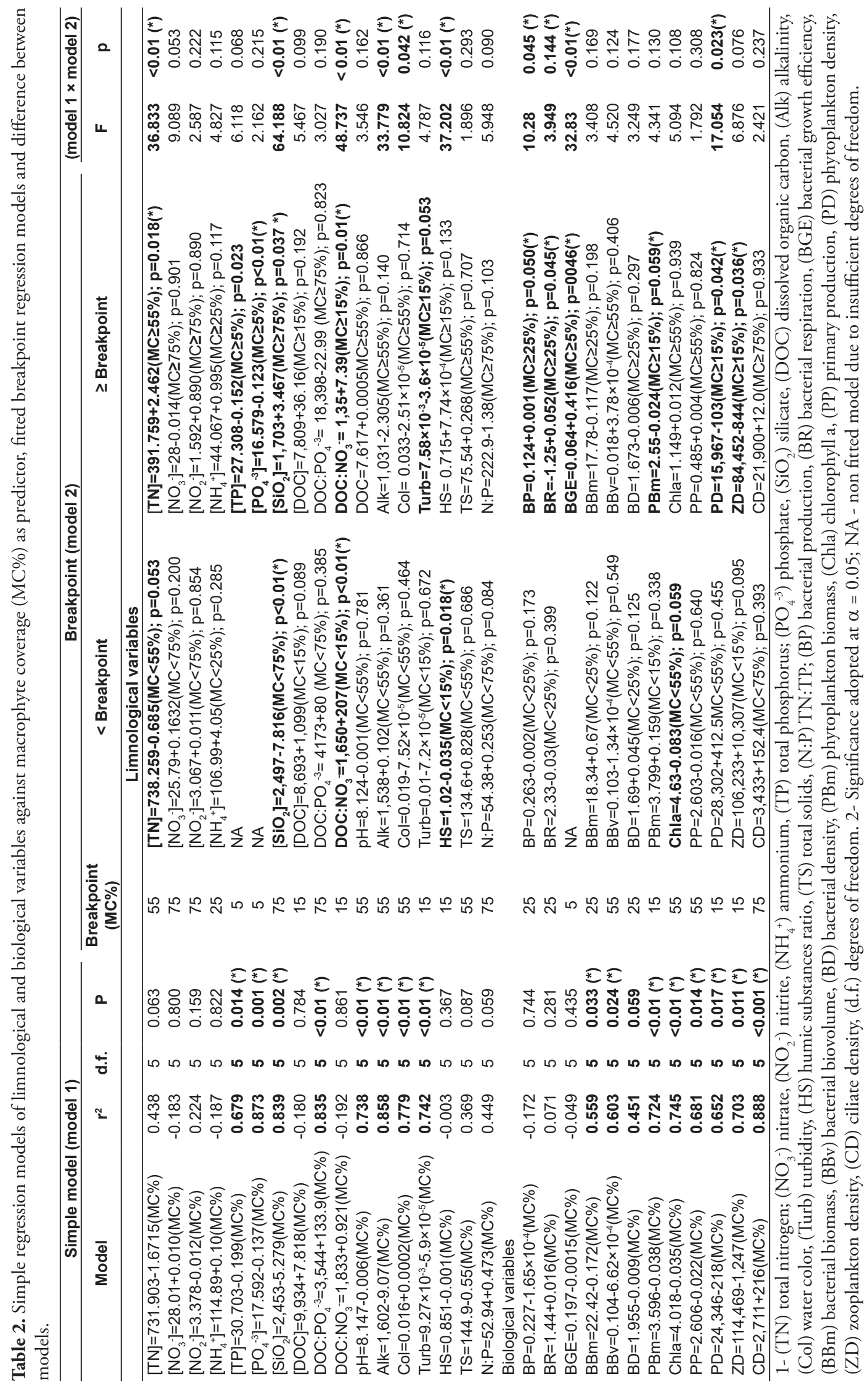




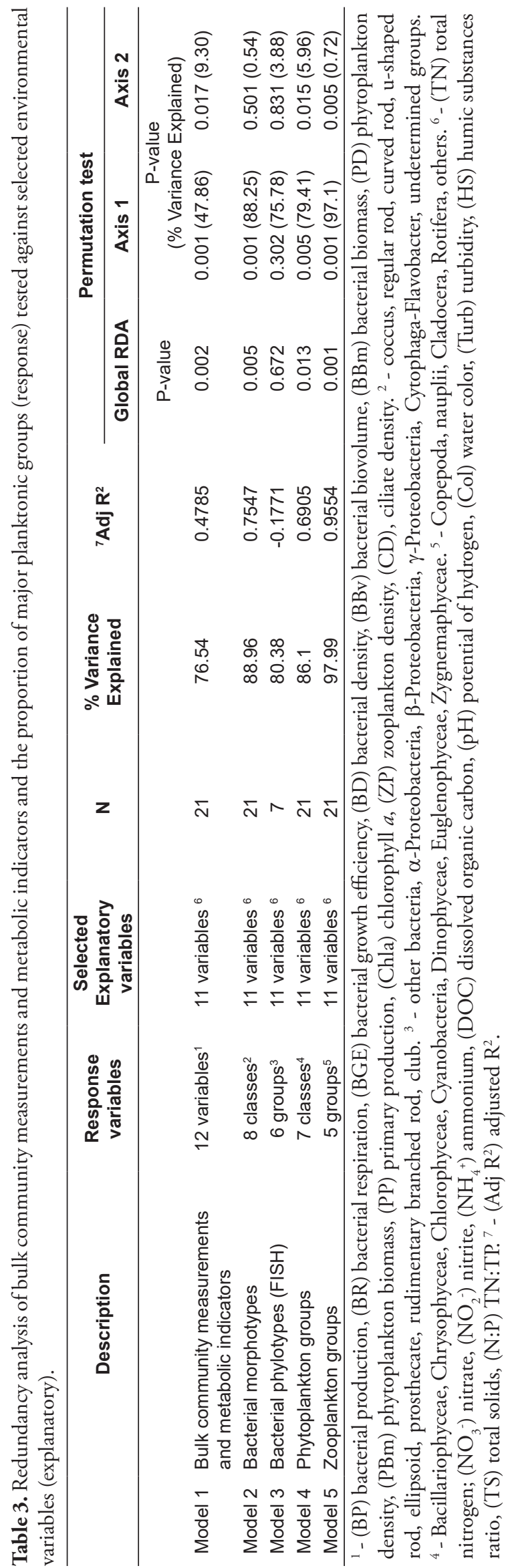


a
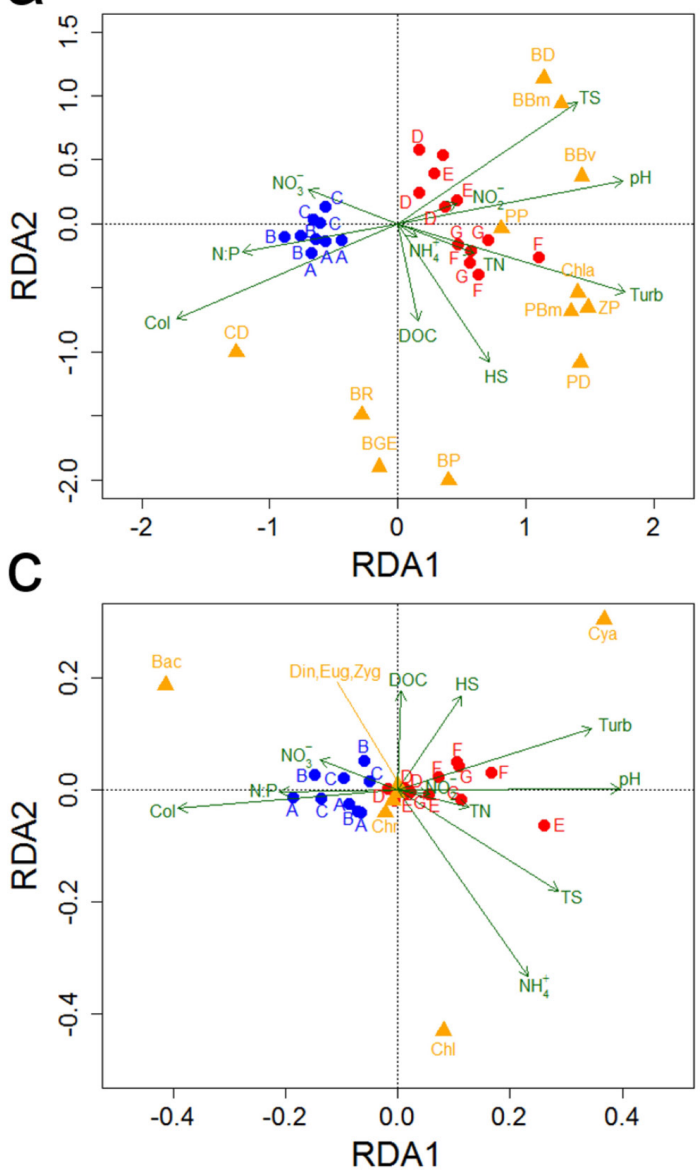

b
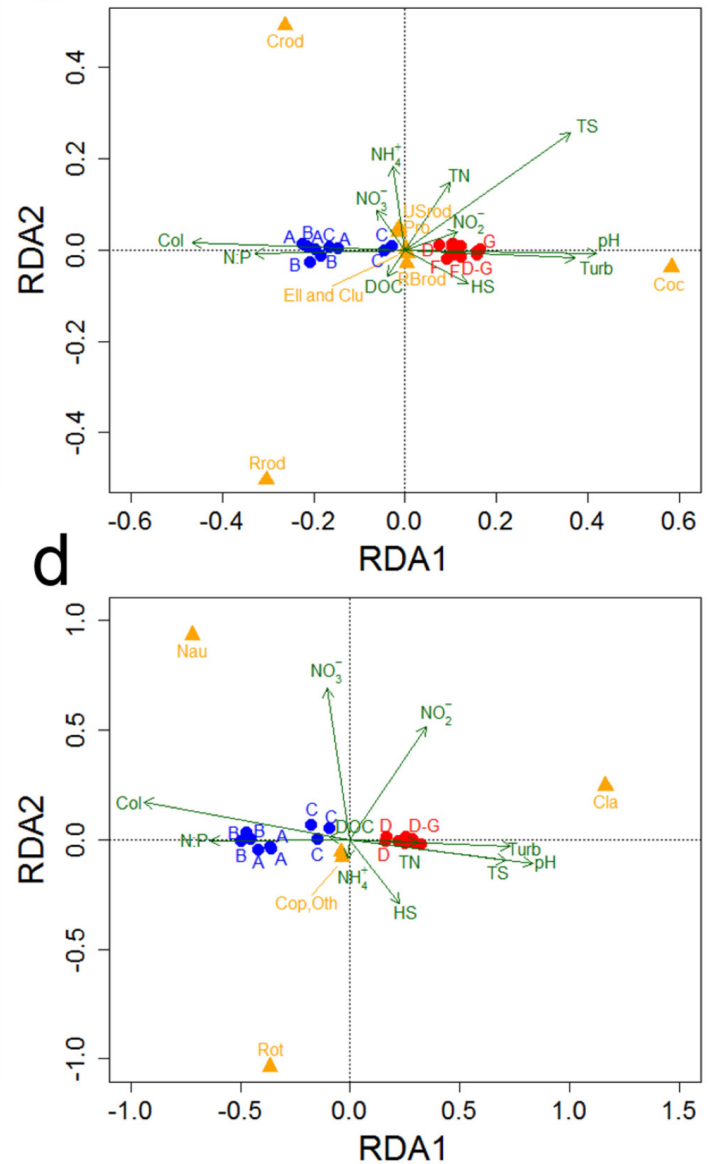

Figure 6. Redundancy Analyses (RDA) of (a) Bulk community measurements and metabolic rates, (b) Bacterial morphotypes, (c) Phytoplankton groups and (d) Zooplankton groups as response variables and limnological variables as explanatory variables. Refer to Table 2 for more details about the analysis. Colors refer to: yellow, response variables; green, explanatory variables; blue, stations A-C from the littoral zone; red, stations D-G from the pelagic zone.

Abbreviations: (BP) bacterial production, (BR) bacterial respiration, (BGE) bacterial growth efficiency, (BD) bacterial density, (BBv) bacterial biovolume, (BBm) bacterial biomass, $(\mathrm{PD})$ phytoplankton density, (PBm) phytoplankton biomass, (PP) primary production, (Chla) chlorophyll a, (ZP) zooplankton density, (CD), ciliate density, (Coc) coccus, (Rrod) regular rod, (Crod) curved rod, (USrod) u-shaped rod, (Ell) ellipsoid, (Pro) prosthecate, (RBrod) rudimentary branched rod, (Clu) club, (Bac) Bacillariophyceae, (Chr) Chrysophyceae, (Chl) Chlorophyceae, (Cya) Cyanobacteria, (Din) Dinophyceae, (Eug) Euglenophyceae, (Zyg) Zygnemaphyceae, (Cop) Copepoda, (Nau) nauplii, (Cla) Cladocera, (Rot) Rotifera, (Oth) others, (TN) total nitrogen; $\left(\mathrm{NO}_{3}^{-}\right)$nitrate, $\left(\mathrm{NO}_{2}^{-}\right)$nitrite, $\left(\mathrm{NH}_{4}^{+}\right)$ammonium, (DOC) dissolved organic carbon, $(\mathrm{pH})$ potential of hydrogen, (Col) water color, (Turb) turbidity, (HS) humic substances ratio, (TS) total solids, (N:P) TN:TP.

higher in the littoral zone, but peaked in the pelagic zone likely due to the high primary production of phytoplankton. Higher color and lower $\mathrm{pH}$ and alkalinity in the littoral zone can be attributed to the release of organic acids from macrophytes leachates (Farjalla et al., 2001). Colored and humic substances were around two times higher in this zone and $>4$ times higher than in other lakes surveyed in this area (They et al., 2010) or elsewhere in Brazil (Amado et al., 2006).
Submerged macrophytes can be strong competitors for nutrients, reducing significantly their concentrations in the water, especially phosphorus (Huss \& Wehr, 2004; Joniak et al., 2007; Kalff \& Rooney, 2003). This was observed as lower concentration of TP and $\mathrm{PO}_{4}^{-3}$, but also of TN, resulting in high $\mathrm{N}: \mathrm{P}$ and DOC: $\mathrm{PO}_{4}^{-3}$ in the littoral zone. Lower $\mathrm{SiO}_{2}$ in the littoral zone can be attributed to consumption of plants like Spartina (Schreb, Poaceae) (and also periphytic diatoms), 
which are very abundant in the littoral zones of Lake Mangueira.

\subsection{Plankton abundance and composition}

Associated with the chemical zonation, the bacterial abundance, biovolume and biomass increased towards the pelagic area, which can be explained partly by the lower phosphorus concentration in the littoral zone. Bacterioplankton can show a variable response to the interaction between macrophytes and phosphorus, as macrophytes can be associated with low bacterial density and biomass even with addition of phosphorus (Morozova et al., 2011). Conversely, phosphorus amendment in the presence of this plants can induce a positive response in bacteria (Huss \& Wehr, 2004).

Predation could be an alternative explanation for the lower bacterial density, biovolume and changes in morphotypes, as higher ciliate density was found in the littoral zone (Pace \& Cole, 1994), even though bacterial density was not correlated with ciliate density. This pattern is opposite to the higher density of ciliates found outside plant beds in temperate lakes due to higher density of zooplankton predators hiding in the vegetation. However, also in these lakes a higher bacterial density is found outside plant beds (Jürgens \& Jeppesen, 1997), which indicates that other predators may play a role too in controlling bacterial numbers. Heterotrophic nanoflagellates, as one of the largest consumers of bacteria in pelagic environments (Sherr \& Sherr, 2002 and references therein) could be contributing to this pattern, but flagellate density data was not available for this study.

A stronger cascading effect of zooplankton on microbial organisms and phytoplankton in the littoral zone of highly vegetated lakes has been shown by Jeppesen et al. (2002) for temperate lakes with high abundance of zooplankton among the plants. The effect of cladocerans on potential bacterivores in the pelagic zone where practically no other groups were recorded is in accordance with Haukka et al. (2006), who found significant correlations between bacterial community composition and rotifers and naupliar stages of copepods. Contrastingly, studies focusing protist predators in vegetated and unvegetated ecosystems have found that grazing by ciliates (Zingel \& Nóges, 2008) and flagellates (Torremorell et al., 2015) on bacterial sized-particles is higher in unvegetated lakes than in vegetated ones, suggesting that the microbial loop is weaker inside plant beds. Accordingly, in our study the lower density, and biomass of bacteria in the littoral zone is an indicative of a lower potential for energy and matter transference through microbial loop. Lower microbial loop efficiency has been attributed to tropical lakes in comparison with temperate lakes, associated with longer food chains and higher rates of community respiration in the former (Sarmento, 2012). However, whether this applies also to subtropical shallow lakes is still to be elucidated.

Changes in cell shape in response to predation favoring filamentous and aggregate forms have been found in pelagic areas in temperate lakes (Jürgens \& Jeppesen, 1997). In lake Mangueira, we observed the same pattern with a higher diversity of morphotypes in the littoral zone and a larger fraction of expectedly more edible, coccoid forms in the pelagic zone. This can be also a response to increased competition for nutrients with phytoplankton, as this morphotype favors the bacterial surface:volume ratio (Cotner $\&$ Biddanda, 2002).

The steep changes in the bacterial assembly composition (FISH data) as well as in morphotypic diversity along the transect suggest the existence of two distinct separate assemblies. The proportion of bacteria (total cells detected by FISH probes) of undetermined groups was lower in the littoral zone, peaked in the interface zone, and then became stable and higher in the pelagic zone, suggesting that the interface is a more complex and diverse zone, and a possible influence of DOM mixing from different sources. Horner-Devine et al. (2003) pointed out that $\alpha$-proteobacteria has a $U$-shaped relationship with productivity, $\beta$ - proteobacteria shows no relationship, while Cytophaga Flavobacter has a unimodal response. At lower taxonomic resolution we recorded unimodal behavior of the major groups of $\alpha$-, $\beta$ - and $\gamma$-proteobacteria, with higher abundances around the interface zone. It has been found that clear lakes, with higher coverage of submerged macrophytes, are dominated species of Bacteroidetes in clone libraries. Members of this group are known to grow on cellulose and chitin biopolymers, i.e., on high molecular weight DOM, which is associated with plant decay (Van der Gucht et al., 2005). Our results are also in accordance with next generation sequencing data, which also reveals consistence differences in main bacterial groups among open water and macrophyte dominated sites (Mentes et al., 2018). For instance, in the submerged macrophyte Utricularia vulgaris dominated sites there was a dominance of Chlorobi, possibly related to low oxygen levels, whereas Cyanobacteria were present 
in expressive proportions only in open water sites (Mentes et al., 2018).

Zooplankton and phytoplankton abundances increased markedly along the gradient and also showed assembly structural changes. Cladocerans were the dominant organisms in the pelagic area. Several studies from subtropical lakes have recorded cladoceran (notably Daphnia Müller, 1785) avoidance of macrophyte beds due to high risk of predation by fish or macroinverterbrates (Meerhoff et al., 2006; Meerhoff et al., 2007; Trochine et al., 2008; Sagrario \& Balseiro, 2010), which is opposite to findings in temperate lakes where they act as a refuge for zooplankton (Lauridsen et al., 2001; Burks et al., 2002). Dominance of rotifers and nauplii also indicates high predation risk in the macrophyte zone in Lake Mangueira.

For phytoplankton, there was an increase in number, biomass and production (density, biomass, chlorophyll $a$ and primary production) and proportion of cyanobacteria along the gradient. These algae usually thrive at nutrient rich conditions in shallow warm, well-mixed lakes with high $\mathrm{pH}$ and low N:P ratio (Steinberg \& Hartmann, 1988). This group along with diatoms has also been found to be dominant in this Lake in a previous study (Crossetti et al., 2007).

\subsection{Bacterial metabolism}

Macrophyte-derived carbon has long been recognized as an important source for bacterioplankton and could be a possible explanation for the apparent decoupling between bacteria and the pelagic food web often reported in the literature (Søndergaard et al., 1997 and references therein). In fact, the contribution of macrophyte+periphyton DOC for bacteria can be as high as $85 \%$ in macrophyte dominated systems (Kluijver et al., 2015), supporting higher rates of bacterial production in comparison to systems without macrophytes (Søndergaard et al., 1997).

In lake Mangueira, however, the higher BP and lower $\mathrm{BR}$ in the pelagic zone explained the overall pattern of increase in BGE along the transect. This can be explained by the high maintenance costs of growth under high proportion of refractory DOC and/or low concentrations/low quality of DOC and low nutrients (del Giorgio \& Cole, 1998) in the vegetated areas. Thus, if we assume that productivity increases with increasing algal biomass (Cotner \& Biddanda, 2002), the increase in BGE pattern in the pelagic zone is to be expected (Kritzberg et al., 2005).
Another important consideration concerning BGE is that BR in lake Mangueira is very low. The lowest respiration rates recalculated by Farjalla et al. (2009) for a humic lake in Rio de

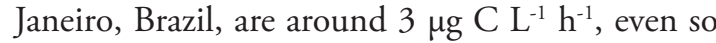
higher than all respiration rates but one recorded in the present study. The higher respiration rates adjacent to the macrophyte beds may indicate, as shown by these authors, that the labile DOC released by the leaching of macrophyte tissues can promote high initial respiration rates, but as the carbon pool becomes more refractory around the interface zone, it prevents further respiration (They et al., 2013b). In fact, respiration in Lake Mangueira is undetectable in dark bottles incubated with water collected from the littoral zone during periods shorter than 5 days (They et al., 2013a, b). Compounds derived from macrophytes can be composed of polymeric compounds (humic substances) that covalently bind to enzymes, making them unfunctional (Chróst, 1991). However, Reitner et al. (1999) recorded lower bacterial numbers and production in unvegetated areas compared to vegetated areas covered by the emergent macrophyte Phragmites australis, but this may be due the fact that areas inside the macrophytes stands surprisingly showed a higher fraction of labile DOC in their study. Additionally, it is likely that the specific composition of macrophytes may play a role in determining the net effect on bacteria.

These metabolic results imply that the bacterial metabolism is constrained by the carbon quality available in the macrophyte-dominated zone. This is in agreement with the findings of Torremorell et al. (2015), which found that bacterial production was controlled by DOC quality (higher aromaticity) in a macrophyte-dominated lake with comparison to a phytoplankton-dominated lake.

\subsection{Effects of different functional groups of macrophytes in shallow lakes plankton ecology}

Even though floating and emergent macrophytes were not recorded in the sampling points, given their occurrence very close to them, it is important to consider how different functional groups of macrophytes may affect lake plankton. In South American shallow lakes geographically close and very similar to Lake Mangueira, the permanent coverage of floating macrophytes can reduce light penetration and maintain low levels of oxygen and high concentrations of nutrients, inducing the predominance of cyanobacteria and diatoms 
(Sinistro et al., 2006; Izaguirre et al., 2004). Emergent macrophytes, at the other hand, due to their structural tissues, possess relative high amounts of lignified and cellulosic tissues that resemble those of terrestrial plants. In consequence, organic leachates from these macrophytes are rich in humic substances (Wetzel, 1992), which can affect enzyme functioning (of bacteria and phytoplankton) (Chróst, 1991). Stronger effects, however, seem to be linked with submerged macrophytes, which can produce allelopathic compounds (Leu et al., 2002; Gross et al., 2007; Körner \& Nicklisch, 2002; van Donk \& van de Bund, 2002; Leu et al., 2002; Mulderij et al., 2007). Allelopathic effects of submerged macrophytes on phytoplankton and cyanobacteria have been extensively described. Many of the macrophytes occurring in Lake Mangueira such as Myriophyllum and Potamogeton have such capacities (Gross et al., 1996; Körner \& Nicklisch, 2002; see also review in Gross et al., 2007). Potamogeton pectinatus extracts have been reported to delay the log phase of bacterial growth and to inhibit alkaline phosphatase activity in experimental regrowth cultures (They et al., 2015).

\subsection{Limitations and perspectives}

The transect sampled was a detailed study and part of a larger sampling program in which 4 additional transects were sampled in an identical fashion for limnological variables and phytoplankton along one year in Lake Mangueira (They et al., 2015). The patterns were consistent through time and remarkably similar, with increasing phosphorus (TP and $\mathrm{PO}_{4}^{-3}$ ), chlorophyll $a$, phytoplankton biomass and contribution of cyanobacteria towards the pelagic zones (They et al., 2015). Thus, this is a consistent pattern that is repeated in lake Mangueira and is likely to occur in other lakes with similar morphometry and macrophyte coverage under the same climate. Even though it is restricted to a single transect, our data clearly demonstrates that the $\mathrm{MC} \%$ is a key factor and a good predictor regulating bacterial metabolism and plankton diversity patterns in this lake.

The lake Mangueira has a large ratio of littoral to pelagic zone and the patterns found in our study may have a huge, yet unaccounted effect on the whole lake metabolism. The mechanisms of these interactions need to be better understood in order to elucidate whether these patterns apply to other types of lakes (e.g. smaller, temperate, boreal and tropical ones). The continuous growth of macrophytes in subtropical shallow lakes, as opposed to temperate and boreal lakes, may impart very strong regulation over the planktonic components, especially bacterial metabolism, which is central to understand carbon cycling in these poorly studied ecosystems. Nevertheless, the role of lake morphometry, seiche and other physical variables need to be evaluated in order to disentangle their effects from "pure effects" of macrophytes, which should be ideally done with manipulative removal of macrophytes or ecological mathematical modelling.

Another important aspect to be considered is the high dependency of the FISH technique on the ribosome pool inside the cells (Bouvier \& del Giorgio, 2003), resulting in low detection of bacteria because of low activity, as already found for Mangueira and other southern Brazilian coastal lakes (They et al., 2010; They et al., 2013a; They et al., 2013b). For this reason, the discussion about diversity using FISH in these lakes needs to be taken with caution and other methods (e.g. metagenomics, CARD-FISH) that do not rely or rely less on the ribossomal pool should be considered in future studies.

\section{Conclusion}

In this study, we have observed lower concentrations of nutrients (mainly phosphorus), chlorophyll $a$, densities of most planktonic groups (bacterial, phytoplankton and zooplankton), and bacterial metabolism (production and BGE) in the littoral zone where macrophytes prevail in lake Mangueira. Additionally, strong changes in plankton composition for all major groups were found along the sampled transect. Combined effects of macrophytes on quantity/quality of nutrients and substrates, indirect effects on bacterial grazers, plus additional putative direct allelopathic effects allow us to draw an overall scenario of less efficient microbial loop in areas covered by macrophytes. This has important implications for trophic structure and lake global metabolism. In conclusion, these plants exert a strong effect on the structuring of plankton diversity and metabolism, which has important implications for sampling design and ecological processes in this and likely in other large subtropical shallow lakes.

\section{Acknowledgements}

This work was supported by the Brazilian agency CNPq/MCT, Sistema Hidrológico do Taim / Taim Hydrological System, Site 7, part of the Brazilian network of Long Term Ecological Research-PELD. This study was developed as part of the Master Thesis of $\mathrm{Ng}$ Haig They at the Post Graduation Program in Ecology of the Universidade Federal do Rio Grande 
do Sul. Haig They was granted a scholarship from The National Council for Scientific and Technological Development (CNPq, process no 133819/2006-0). Special thanks go to Erik Jeppesen for invaluable comments on the manuscript. The authors also gratefully thank Dr. Luciane Crossetti and Dr Laura Utz for analyses of phytoplankton and ciliates, respectively, and Dr. Tiago Ferreira for providing PVI data. We are also grateful to Dr.Anne Mette Poulsen for revising the text.

\section{References}

AMADO, A.M., FARJALLA, V.F., ESTEVES, F.A., BOZELLI, R.L., ROLAND, F. and ENRICHPRAST, A. Complementary pathways of dissolved organic carbon removal pathways in clear-water Amazonian ecosystems: photochemical degradation and bacterial uptake. FEMS Microbiology Ecology, 2006, 56(1), 8-17. http://dx.doi.org/10.1111/ j.1574-6941.2006.00028.x. PMid:16542400.

AMERICAN PUBLIC HEALTH ASSOCIATION APHA. Standard Methods for the examination of Water and Wastewater. Washington: APHA, 2006.

BERGGREN, M., LAPIERRE, J.F. and DEL GIORGIO, P.A. Magnitude and regulation of bacterioplankton respiratory quotient across freshwater environmental gradients. The ISME Journal, 2012, 6(5), 984993. http://dx.doi.org/10.1038/ismej.2011.157. PMid:22094347.

BORCARD, D., GILLET, F. and LEGENDRE, P. Numerical Ecology with R. New York: Springer, 2011. http://dx.doi.org/10.1007/978-1-4419-7976-6.

BOUVIER, T. and DEL GIORGIO, P.A. Factors influencing the detection of bacterial cells using fluorescence in situ hybridization (FISH): a quantitative review of published reports. FEMS Microbiology Ecology, 2003, 44(1), 3-15. http:// dx.doi.org/10.1016/S0168-6496(02)00461-0. PMid:19719646.

BRAUN-BLANQUET, J. Pflanzensoziologie, New York: Springer, 1964. http://dx.doi.org/10.1007/978-37091-8110-2.

BURKS, R.L., LODGE, D.M., JEPPESEN, E. and LAURIDSEN, T.L. Diel horizontal migration of zooplankton: costs and benefits of inhabiting the littoral. Freshwater Biology, 2002, 47, 343-365. https://doi.org/10.1046/j.1365-2427.2002.00824.x

CHRÓST, R. Microbial enzymes in aquatic environments. New York: Springer, 1991. http://dx.doi. org/10.1007/978-1-4612-3090-8.

COLE, J.J. Aquatic microbiology for ecosystem scientists: new and recycled paradigms in ecological microbiology. Ecosystems, 1999, 2(3), 215-225. http://dx.doi.org/10.1007/s100219900069.
COTNER, J.B. and BIDDANDA, B.A. Small players, large role: microbial influence on biogeochemical processes in pelagic aquatic ecosystems. Ecosystems, 2002, 5(2), 105-1. http://dx.doi.org/10.1007/ s10021-001-0059-3.

CRAWLEY, M.J. The $R$ Book. England: John Wiley and Sons, 2007. http://dx.doi. org/10.1002/9780470515075.

CROSSETTI, L.O., CARDOSO, L.S., CALLEGARO, V.L.M., ALVES-DA-SILVA, S.M., WERNER, V.R., ROSA, Z.M. and MOTTA-MARQUES, D. Influence of the hydrological changes on the phytoplankton structure and dynamics in a subtropical wetland-lake system. Acta Limnologica Brasiliensia, 2007, 19, 315-329.

DEL GIORGIO, P.A. and COLE, J. Bacterial growth efficiency in natural aquatic systems. Annual Review of Ecology Evolution and Systematics, 1998, 29(1), 503-541. http://dx.doi.org/10.1146/annurev. ecolsys.29.1.503.

DEL GIORGIO, P.A., COLE, J.J. and CIMBLERIS, A. Respiration rates in bacteria exceed phytoplankton production in unproductive aquatic systems. Nature, 1997, 385(6612), 148-151. http://dx.doi. org/10.1038/385148a0.

DOCHERTY, K.M., YOUNG, K.C., MAURICE, P.A. and BRIDGHAM, S.D. Dissolved organic matter concentration and quality influences upon structure and function of freshwater microbial communities. Microbial Ecology, 2006, 52(3), 378388. http://dx.doi.org/10.1007/s00248-006-9089-x. PMid:16767520.

FARJALLA, V.F., ANESIO, A.M., BERTILSSON, S. and GRANÉLI, W. Photochemical reactivity of aquatic macrophyte leachates: abiotic transformations and bacterial response. Aquatic Microbial Ecology, 2001, 24, 187-195. http://dx.doi.org/10.3354/ ame024187.

FARJALLA, V.F., MARINHO, C.C., FARIA, B.M., AMADO, A.M., ESTEVES, F.A., BOZELLI, R.L. and GIROLDO, D. Synergy of fresh and accumulated organic matter to bacterial growth. Microbial Ecology, 2009, 57(4), 657-666. http://dx.doi.org/10.1007/ s00248-008-9466-8. PMid:18985269.

GLÖCKNER, F.O., FUCHS, B.M. and AMANN, R. Bacterioplankton compositions of lakes and oceans: a first comparison based on Fluorescence In Situ Hybridization. Applied and Environmental Microbiology, 1999, 65(8), 3721-3726. PMid:10427073.

GOLTERMAN, H.L., CLYMO, R.S. and OHNSTAD, M.A.M. Methods for physical and chemical analysis of fresh waters. Great Britain: Billing and Sons Limited Guildford, 1978.

GRAFFELMAN, J. Calibrate: calibration of scatterplot and biplot axes. R package. Version 1.7., 2010 [viewed 
16 Apr 2010. Available from: http://CRAN.Rproject.org/package=calibrate.

GROSS, E.M., HILT, S., LOMBARDO, P. and MULDERIJ, G. Searching for allelopathic effects of submerged macrophytes on phytoplankton - state of the art and open questions. Hydrobiologia, 2007, 584(1), 77-88. http://dx.doi.org/10.1007/s10750007-0591-z.

GROSS, E.M., MEYER, H. and SCHILLING, G. Release and ecological impact of algicidal hydrolysable polyphenols in Myriophyllum spicatum. Phytochemistry, 1996, 41(1), 133-138. http://dx.doi. org/10.1016/0031-9422(95)00598-6.

HAUKKA, K., KOLMONEN, E., HYDER, R., HIETALA, J., VAKKILAINEN, K., KAIRESALO, T., HAARIO, H. and SIVONEN, K. Effect of nutrient loading on bacterioplankton community composition in lake mesocosms. Microbial Ecology, 2006, 51(2), 137-146. http://dx.doi.org/10.1007/ s00248-005-0049-7. PMid:16435168.

HILLEBRAND, H., DÜRSELEN, C.-D., KIRSCHTEL, D., POLLINGHER, U. and ZOHARY, T. Biovolume calculation for pelagic and benthic microalgae. Journal of Phycology, 1999, 35(2), 403-424. http://dx.doi.org/10.1046/j.15298817.1999.3520403.x.

HORNER-DEVINE, M., LEIBOLD, M.A., SMITH, V.H. and BOHANNAN, B.J.M. Bacterial diversity patterns along a gradient of primary productivity. Ecology Letters, 2003, 6(7), 613-622. http://dx.doi. org/10.1046/j.1461-0248.2003.00472.x.

HUSS, A.A. and WEHR, J.D. Strong indirect effects of a submersed aquatic macrophyte, Vallisneria americana, on bacterioplankton densities in a mesotrophic lake. Microbial Ecology, 2004, 47(4), 305-315. PMid:15037963.

IZAGUIRRE, I., O'FARRELL, I., UNREIN, F., SINISTRO, R., SANTOS AFONSO, M. and TELL, G. Algal assemblages across a wetland, from a shallow lake to relictual oxbow lakes (Lower Paraná River, South America). Hydrobiologia, 2004, 511(1), 25-36. http://dx.doi.org/10.1023/ B:HYDR.0000014016.89127.ca.

JEPPESEN, E., SØNDERGAARD, M., JENSEN, J.P., MORTENSEN, E., HANSEN, A.M. and JØRGENSEN, T. Cascading trophic interactions from fish to bacteria and nutrients after reduced sewage loading: an 18-year study of a shallow hypertrophic lake. Ecosystems (New York, N.Y.), 1998, 1(3), 250-267. http://dx.doi.org/10.1007/ s100219900020.

JEPPESEN, E., SØNDERGAARD, M., SØNDERGAARD, M., THEIL-NIELSEN, J. and JÜRGENS, K. Cascading trophic interactions in the littoral zone: an enclosure experiment in shallow lake Stigsholm, Denmark. Archiv für Hydrobiologie,
2002, 153(4), 533-555. http://dx.doi.org/10.1127/ archiv-hydrobiol/153/2002/533.

JESPERSEN, A.M. and CHRISTOFFERSEN, K. Measurements of chlorophyll-a from phytoplankton using ethanol as extraction solvent. Archiv für Hydrobiologie, 1987, 109, 445-454.

JONIAK, T., KUCZYŃSKA-KIPPEN, N. and NAGENGAST, B. The role of aquatic macrophytes in microhabitatual transformation of physicalchemical features of small water bodies. Hydrobiologia, 2007, 584(1), 101-109. http://dx.doi.org/10.1007/ s10750-007-0595-8.

JÜRGENS, K. and JEPPESEN, E. Cascading effects on microbial food web structure in a dense macrophyte canopy. In: E. Jeppesen, M.A. Søndergaard, M.O. Søndergaard and K. Christoffersen, eds. The structuring role of submerged macrophytes in lakes. New York: Springer, 1997, pp. 262-274.

KALFF, J. and ROONEY, N. Submerged macrophytebed effects on water-column phosphorus, chlorophyll a, and bacterial production. Ecosystems, 2003, 6(8), 797-807. http://dx.doi.org/10.1007/s10021-0030184-2.

KAMJUNKE, N., BÖING, W. and VOIGT, H. Bacterial and primary production under hypertrophic conditions. Aquatic Microbial Ecology, 1997, 13, 2935. http://dx.doi.org/10.3354/ame013029.

KEPNER JÚNIOR, R.L.J.R. and PRATT, J.R. Use of fluorochromes for direct enumeration of total bacteria in environmental samples: past and present. Microbiology and Molecular Biology Reviews, 1994, 58(4), 603-615. PMid:7854248.

KIRCHMAN, D. Measuring bacterial biomass production and growth rates from leucine incorporation in natural aquatic environments. In: J.H. Paul, ed. Methods in microbiology. USA: Academic Press, 2001, pp. 227-237. 9th ed., vol. 30. http://dx.doi.org/10.1016/S0580-9517(01)30047-8.

KLUIJVER, A., NING, J., LIU, Z., JEPPESEN, E., GULATI, R.D. and MIDDELBURG, J.J. Macrophytes and periphyton carbon subsidies to bacterioplankton and zooplankton in a shallow eutrophic lake in tropical China. Limnology and Oceanography, 2015, 60(2), 375-385. http://dx.doi. org/10.1002/lno.10040.

KÖRNER, S. and NICKLISCH, A. Allelopathic growth inhibition of selected phytoplankton species by submerged macrophytes. Journal of Phycology, 2002, 38(5), 862-871. http://dx.doi. org/10.1046/j.1529-8817.2002.t01-1-02001.x.

KRITZBERG, E.S., COLE, J.J., PACE, M.M. and GRANÉLI, W. Does autochthonous primary production drive variability in bacterial metabolism and growth efficiency in lakes dominated by terrestrial C inputs? Aquatic Microbial Ecology, 2005, 38, 103-111. http://dx.doi.org/10.3354/ame038103. 
LAURIDSEN, T., JEPPESEN, E., LANDKILDEHUS, F. and SØNDERGAARD, M. Horizontal distribution of cladocerans in arctic Greenland lakes - impact of macrophytes and fish. Hydrobiologia, 2001, 442(1/3), 107-116. http://dx.doi. org/10.1023/A:1017517919996.

LAUSTER, G.H., HANSON, P.C. and KRATZ, T.K. Gross primary production and respiration differences among littoral and pelagic habitats in northern Wisconsin lakes. Canadian Journal of Fisheries and Aquatic Sciences, 2006, 63(5), 1130-1141. http:// dx.doi.org/10.1139/f06-018.

LEU, A., KRIEGER-LISZKAY, A., GOUSSIAS, C. and GROSS, E.M. Polyphenolic allelochemicals from the aquatic angiosperm Myriophyllum spicatum inhibit photosystem II. Plant Physiology, 2002, 130(4), 2011-2018. http://dx.doi.org/10.1104/pp.011593. PMid:12481084.

LIU, J., DAZZO, F.B., GLAGOLEVA, O., YU, B. and JAIN, A.K. CMEIAS: A computer-aided system for the image analysis of bacterial morphotypes in microbial communities. Microbial Ecology, 2001, 41(3), 173-194. http://dx.doi.org/10.1007/ s002480000004. PMid:11391457.

MACKERETH, F.J.H., HERON, J. and TALLING, J.F. Water analysis: some revised methods for limnologists. Ambleside: Freshwater Biological Association, 1989.

MAECHLER, M., et al. Sfsmisc: utilities from Seminar für Statistik. R Package. Version 1.0-16 [online], 2011 [viewed 15 June 2011]. Available from: http:// CRAN.R-project.org/package=sfsmisc.

MASSANA, R., GASOL, J.M., BJØRNSEN, P.K., BLACK-BURN, N., HAGSTRÖM, Å., HIETANEN, S., HYGUM, B.H., KUPARINEN, J. and PEDRÓS-ALIÓ, C. Measurement of bacterial size via image analysis of epifluorescence preparations: description of an inexpensive system and solutions to some of the most common problems. Scientia Marina, 1997, 61, 397-407.

MEERHOFF, M., FOSALBA, C., BRUZZONE, C., MAZZEO, N., NOORDOVEN, W. and JEPPESEN, E. An experimental study of habitat choice by Daphnia: plants signal danger more than refuge in subtropical lakes. Freshwater Biology, 2006, 51(7), 1320-1330. http://dx.doi.org/10.1111/ j.1365-2427.2006.01574.x.

MEERHOFF, M., IGLESIAS, C., MELLO, F.T., CLEMENTE, J.M., JENSEN, E., LAURIDSEN, T.L. and JEPPESEN, E. Effects of habitat complexity on community structure and predator avoidance bahavior of littoral zooplankton in temperate versus subtropical shallow lakes. Freshwater Biology, 2007, 52(6), 1009-1021. http://dx.doi.org/10.1111/ j.1365-2427.2007.01748.x.

MENTES, A., SZABÓ, A., SOMOGYI, B., VAJNA, B., TUGYI, N., CSITÁRI, B., VÖRÖS, L. and FELFÖLDI, T. Differences in planktonic microbial communities associated with three types of macrophytes stands in a shallow lake. FEMS Microbiology Ecology, 2018, 94(2), 1-12. http:// dx.doi.org/10.1093/femsec/fix164. PMid:29206918.

MOROZOVA, O.V., RATUSHNYAK, A.A., TARASOV, O.Y. and TRUSHIN, M.V. The role of bacterioplankton and aquatic macrophytes in autoputification of hydroecosystems polluted with phosphorus. Middle East Journal of Scientific Research, 2011, 7, 346-351.

MULDERIJ, G., VAN NES, E.H. and VAN DONK, E. Macrophyte-phytoplankton interactions: the relative importance of allelopathy versus other factors. Ecological Modelling, 2007, 204(1-2), 85-92. http:// dx.doi.org/10.1016/j.ecolmodel.2006.12.020.

NORLAND, S. The relationship between biomass and volume of bacteria. In: P.F. Kemp, B.F. Sherr, E.B. Sherr and J.J. Cole, eds. Handbook of methods in aquatic microbial ecology. USA: Lewis Publishers, 1993, pp. 339-345.

NORLIN, J.V., BAILEY, S.E. and ROSS, L.C.M. Submerged macrophytes, zooplankton and the predominance of low-over high-chlorophyll states in western boreal, shallow-water wetlands. Hydrobiologia, 2005, 50, 868-881.

OKSANEN, J., BLANCHET, F.G., KINDT, R., LEGENDRE, P., MINCHIN, P.R., O'HARA, R.B., SIMPSON, G.L., SOLYMOS, P., STEVENS, M.H.H. and WAGNER, H. Vegan: community ecology package. R package. Version 2.0-0 [online] 2011 [viewed 02 April 2011]. Available from: http:// CRAN.R-project.org/package $=$ vegan

PACE, M.L. and COLE, J.J. Comparative and experimental approaches to top-down and bottom-up regulation of bacteria. FEMS Microbiology Ecology, 1994, 28(2), 181-193. http://dx.doi.org/10.1007/ BF00166807. PMid:24186444.

PERNTHALER, J., GLÖCKNER, F.-O., SCHÖNHUBER, W. and AMANN, R. Fluorescence in situ hybridization (FISH) with rRNA-targeted oligonucleotide probes. In: Paul, J.H., ed. Methods in microbiology. USA: Academic Press, 2001, pp. 207-226. Vol. 30. http://dx.doi.org/10.1016/S05809517(01)30046-6.

R DEVELOPMENT CORE TEAM. $R$ : A language and environment for statistical computing [online]. Vienna: R Foundation for Statistical Computing, 2011 [viewed 04 Nov 2011]. Available from: http:// www.R-project.org/.

REITNER, B., HERZIG, A. and HERNDL, G.J. Dynamics in bacterioplankton production in a shallow, temperate lake (Lake Neusiedl, Austria): evidence for dependence on macrophyte production rather on phytoplankton. Aquatic Microbial Ecology, 1999, 19, 245-254. http://dx.doi.org/10.3354/ ame019245. 
ROLAND, F., CARACO, N.F., COLE, J.J. and DEL GIORGIO, P.A. Rapid and precise determination of dissolved oxygen by spectrophotometry: evaluation of interference from color and turbidity. Limnology and Oceanography, 1999, 44(4), 1148-1154. http:// dx.doi.org/10.4319/lo.1999.44.4.1148.

SAGRARIO, M.A.G. and BALSEIRO, E. The role of macroinvertebrates and fish in regulating the provision by macrophytes of refugia for zooplankton in a warm temperate shallow lake. Freshwater Biology, 2010, 55(10), 2153-2166. http://dx.doi. org/10.1111/j.1365-2427.2010.02475.x.

SARMENTO, H. New paradigms in tropical limnology: the importance of the microbial food web. Hydrobiologia, 2012, 686(1), 1-14. http://dx.doi. org/10.1007/s10750-012-1011-6.

SCHEFFER, M. and JEPPESEN, E. Alternative stable states. In: Jeppesen, E., Søndergaard, M.A., Søndergaard, M.O. and Christoffersen, K., eds. The structuring role of submerged macrophytes in lakes. New York: Springer, 1997, pp. 397-406.

SCHEFFER, M., HOSPER, S.H., MEIJER, M.L., MOSS, B. and JEPPESEN, E. Alternative equilibria in shallow lakes. Trends in Ecology \& Evolution, 1993, 8(8), 275-279. http://dx.doi.org/10.1016/01695347(93)90254-M. PMid:21236168.

SCHULTZ, R. and DIBBLE, E. Effects of invasive macrophytes on freshwater fish and macroinvertebrate communities: the role of invasive plant traits. Hydrobiologia, 2012, 684(1), 1-14. http://dx.doi. org/10.1007/s10750-011-0978-8.

SHERR, E.B. and SHERR, B.F. Significance of predation by protists in aquatic microbial food webs. Antonie van Leeuwenhoek, 2002, 81(1-4), 293-308. http://dx.doi.org/10.1023/A:1020591307260. PMid: 12448728.

SINISTRO, R., IZAGUIRRE, I. and ASIKIAN, V. Experimental study on the microbial plankton community in a South American wetland (Lower Parana River Basin) and the effect of the light deficiency due to the floating macrophytes. Journal of Plankton Research, 2006, 28(8), 753-768. http:// dx.doi.org/10.1093/plankt/fbl008.

SMITH, D.C. and AZAM, F. A simple, economical method for measuring bacterial protein synthesis rates in sea water using ${ }^{3} \mathrm{H}$-leucine. Marine Microbial Food Webs, 1992, 6, 107-109.

SØNDERGAARD, M. and MOSS, B. Impact of submerged macrophytes on phytoplankton in shallow freshwater lakes. In: Jeppesen, E., Søndergaard, M.A., Søndergaard, M.O., Christoffersen, K., eds. The structuring role of submerged macrophytes in lakes. New York: Springer, 1997, pp. 115-132.

SØNDERGAARD, M., THEIL-NIELSEN, J., CHRISTOFFERSEN, K., SCHLÜTER, L., JEPPESEN, E. and SØNDERGAARD, M.
Bacterioplankton and carbon turnover in a dense macrophyte canopy. In: Jeppesen, E., Søndergaard, M.A., Søndergaard, M.O. and Christoffersen, K., eds. The structuring role of submerged macrophytes in lakes. New York: Springer, 1997, pp. 250-261.

STEINBERG, C.W. and HARTMANN, H.M. Planktonic bloom-forming Cyanobacteria and the eutrophication of lakes and rivers. Freshwater Biology, 1988, 20(2), 279-287. http://dx.doi. org/10.1111/j.1365-2427.1988.tb00452.x.

STROME, D.J. and MILLER, M.C. Photolytic changes in dissolved humic substances. Verhandlungen der Internationalen Vereinigung für Theoretische und Angewandte Limnologie, 1978, 20, 1248-1254.

SUN, J. and LIU, D. Geometric models for calculating cell biovolume and surface area for phytoplankton. Journal of Plankton Research, 2003, 25(11), 13311346. http://dx.doi.org/10.1093/plankt/fbg096.

THEY, N.H., FERREIRA, T.F., MARQUES, D.M., RODRIGUES, L.R., SILVEIRA, S.B., ARRIADA, A.A., CROSSETTI, L.O., CARDOSO, L.S. and FRAGOSO JUNIOR, C.R. Allelopathic effects of macrophytes in subtropical shallow lakes. In: J.E. Price, ed. New Developments in Allelopathy Research. New York: Nova Science Publishers, 2015, pp. 89134.

THEY, N.H., MARQUES, D.M., SOUZA, R.S. and RIBEIRO RODRIGUES, L. Short-term photochemical and biological unreactivity of macrophyte-derived dissolved organic matter in a subtropical shallow lake. Journal of Ecosystems, 2013b, 316709, 1-9. http://dx.doi. org/10.1155/2013/316709.

THEY, N.H., MARQUES, D.M.M., JEPPESEN, E. and SØNDERGAARD, M. Bacterioplankton in the littoral and pelagic zones of shallow lakes. Hydrobiologia, 2010, 646(1), 311-326. http://dx.doi. org/10.1007/s10750-010-0177-z.

THEY, N.H., MOTTA MARQUES, D. and SOUZA, R.S. Lower respiration in the littoral zone of a subtropical shallow lake. Frontiers in Microbiology, 2013a, 3(434), 1-10. PMid:23293635.

TORREMORELL, A., PÉREZ, G., LAGOMARSINO, L., HUBER, P., QUEIMALIÑOS, C., BUSTINGORRY, J., FERMANI, P., LLAMES, M.E. and UNREIN, F. Microbial pelagic metabolism and CDOM characterization in a phytoplanktondominated versus a macrophyte-dominated shallow lake. Hydrobiologia, 2015, 752(1), 203-221. http:// dx.doi.org/10.1007/s10750-014-2057-4.

TROCHINE，C., BALSEIRO, E.G. and MODENUTTI, B.M. Zooplankton of fishless ponds of northern Patagonia: insights into predation effects of Mesostoma ehrenbergii. International Review of Hydrobiology, 2008, 93(3), 312-327. http://dx.doi. org/10.1002/iroh.200711011. 
VAN DEN HOEK, C., MANN, D.G.H. and JAHNS, M. Algae: an introduction to phycology. London: Cambridge University Press, 1998.

VAN DER GUCHT, K., VANDEKERCKHOVE, T., VLOEMANS, N., COUSIN, S., MUYLAERT, K., SABBE, K., GILLIS, M., DECLERK, S., DE MEESTER, L. and VYVERMAN, W. Characterization of bacterial communities in four freshwater lakes differing in nutrient load and food web structure. FEMS Microbiology Ecology, 2005, 53(2), 205-220. http://dx.doi.org/10.1016/j. femsec.2004.12.006. PMid:16329941.

VAN DONK, E. and VAN DE BUND, W.J. Impact of submerged macrophytes including charophytes on phyto- and zooplankton communities: allelopathy versus other mechanisms. Aquatic Botany, 2002, 72(3-4), 261-274. http://dx.doi.org/10.1016/S03043770(01)00205-4.

WETZEL, R.G. and LIKENS, G.E. Limnological Analyses. New York: Springer, 2000. http://dx.doi. org/10.1007/978-1-4757-3250-4.

WETZEL, R.G. Gradient-dominated ecosystems: sources and regulatory functions of dissolved organic matter in freshwaters ecosystems. Hydrobiologia,
1992, 229(1), 181-198. http://dx.doi.org/10.1007/ BF00007000.

WICKHAM, H. Ggplot2: elegant graphics for data analysis. $R$ package, New York: Springer, 2009. Available from: http://www.bioinformaticslaboratory. nl/twikidata/pub/Education/ComputinginR/ ggplot2-book.pdf.

WU, Q.L., ZWART, G., WU, J., KAMST-VAN AGTERVELD, M.P., LIU, S. and HAHN, M.W. Submersed macrophytes play a key role in structuring bacterioplankton community composition in the large, shallow, subtropical shallow Taihu Lake, China. Environmental Microbiology, 2007, 9(11), 2765-2774. http://dx.doi.org/10.1111/j.14622920.2007.01388.x. PMid:17922760.

ZINGEL, P. and NÓGES, T. Protozoan grazing in shallow macrophyte- and plankton lakes. Fundamental and Applied Limnology. Archiv für Hydrobiologie, 2008, 171(1), 15-25. http://dx.doi. org/10.1127/1863-9135/2008/0171-0015.

Received: 29 July 2017 Accepted: 03 May 2019 